\title{
Pieter Bruegels Kruisdraging: een proeve van 'close-reading'*
}

Picter Brucgel Krussiragng Wenen Kunsthistorisches Muscum
Met het onderhavige artikel wil $1 \mathrm{k}$ een bijdrage leveren tot de 1 conologie van het zestiende eeuwse landschap, in het bij/onder tot de betehenis en functie van het figurale voorstellingselement Ik w1l voornamelijk mijn aandacht richten op Pieter Bruegels Kruisdraging (1 564) in Wenen (afb I) Dit schildetij is het doelwit geweest van reeds vele inhoudelijke interpretaties en $1 \mathrm{k}$ zal net pretenderen een geheel nieuwe visie op dit schilderij te presenteren Toch is het mijns inziens de moerte waard nog eens stil te staan bij een aantal afzonderlijke moticven die het mogelijk maken het grondthema van de voorstelling beter te begrijpen Bovendien stelt het schilderij $\mathrm{mly}$ in staat aan te tonen dat er niet alleen, zoals altijd is gezegd, in stılistisch opzicht sprake is van een samenhangende landschapstraditte van Patinir tot Bruegel, maar ook in iconografisch op/1cht Daarnaast wil 1k ingaan op enige

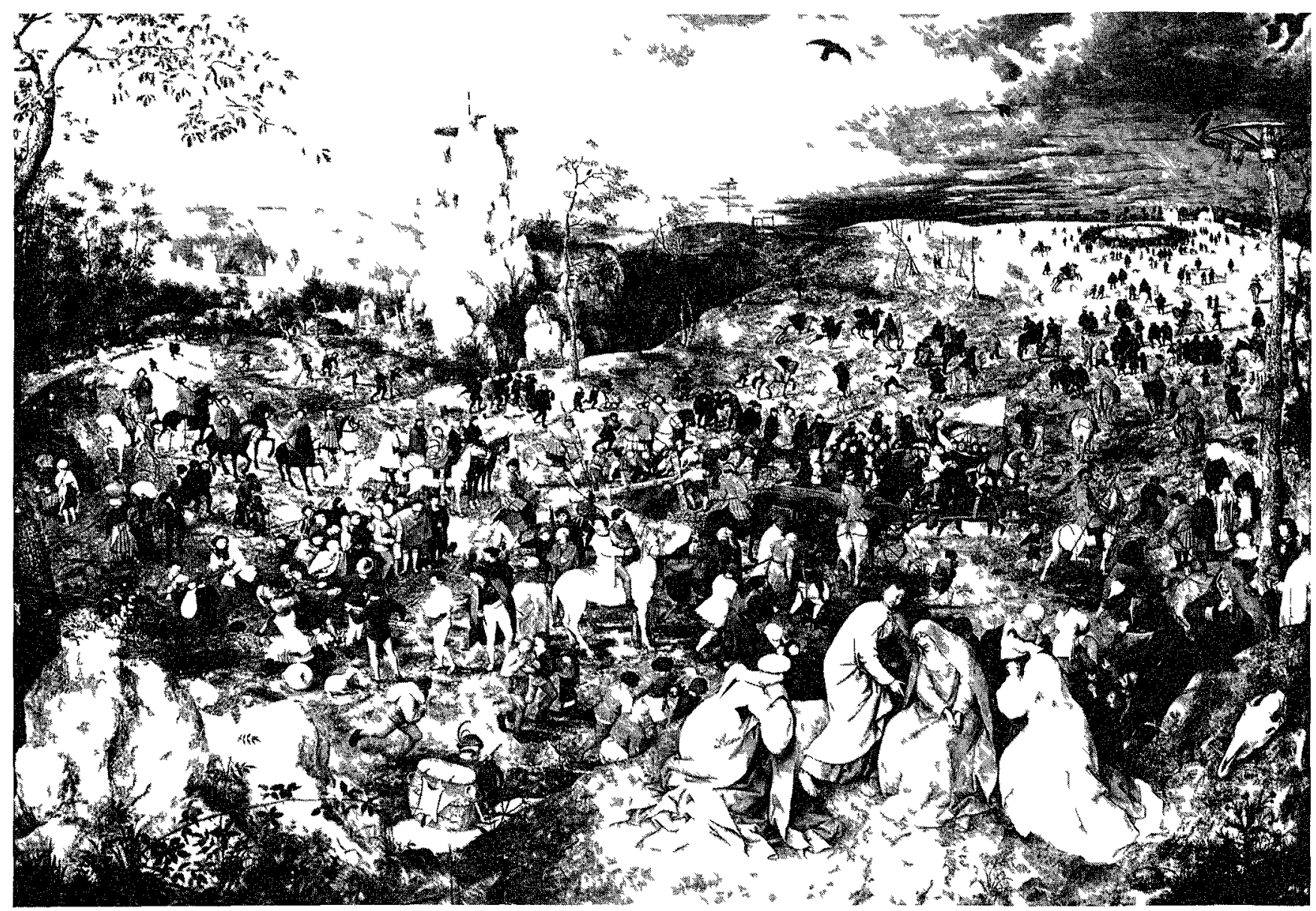


punten van kritiek die tegen de 1conologische interpretatie van Bruegels werk, speciaal zijn Kruzsdragzng, zijn ingebracht. Deze kritıek, die zich richt op de methodische vraag hoe vèr men hierbij mag gaan, raakt tevens een wezenlijk aspekt van de inhoudelijke strekking van het schilderij zelf: de subjectieve inbreng van de beschouwer bij de interpretatie van de voorstelling.

Ik zou willen beginnen met Bruyns opvattingen over de zestiende- en zeventiendeeeuwse beeldtaal (en de kritiek daarop), die zo'n centrale rol spelen in de recente discussie rondom de 1conologische 'interpretabilite1t' van de Nederlandse schilderkunst. In dit licht wil $1 \mathrm{k}$ ook zijn opmerkingen over de subject1vitett van de interpreet bezien.

Bruyn heeft bij verschillende gelegenheden betuigd te geloven in het 'voortleven van de middeleeuwen' in de zestiende- en zeventiende-eeuwse Nederlandse schilderkunst. ${ }^{1}$ Volgens hem is de beeldtaal van deze kunst au fond een behoudende en traditionele. Deze taal is de expressie van een cultuur die sterk geworteld is in het religieus-moraliserende denken van de late middeleeuwen. De allegorie is het fundamentele uitdrukkingsmiddel van deze beeldtaal, ook nog in de zeventiende eeuw, en ligt als een conceptueel programma ten grondslag aan in principe elke 'realistische' voorstelling, zo ook aan genre-schilderijen en landschappen. ${ }^{2}$ Landschappen kunnen tot in het detail gelezen worden als visualiseringen van schriftuurlyke allegorıeen, bijvoorbeeld de levenspelgrimage van de mens door de zondige wereld, en moeten geinterpreteerd worden vanuit morele kategorieen. Niet alleen is dit allegorisme (en moralısme) structureel, maar ook de inkleding van de allegorie in 'realistische', aan het alledaagse leven ontleende beelden is dat. Het feit dat schilders daarbij telkens weer gegrepen hebben naar standaard-repertorres van beeldmotieven maakt deze beeldtaal tot 1ets collectrefs en conventioneels. Het individuele schilderij is daarmee vatbaar voor een gecontroleerde interpretatie van een historisch objectiveerbare, symbolische inhoud. 'Collectieve receptie' staat hier tegenover 'subjectieve receptie', die in Bruyns ogen een anachronisme 1s: vóór de 18 de eeuw is een subjectieve interpretatie van de betekenis van een kunstwerk, dat wil zeggen een interpretatie die zich onttrekt aan de collectıeve beeldtaal en het 'algemeen geldige betekenissysteem', non-existent. ${ }^{3}$

Bruyn had met $\angle 1 j n$ uitspraak over het ontbreken van een subjectıvistısche houding bij de 17 de-eeuwse beschouwer een moderne, 2oste-eeuwse 'l'art pour l'art'-esthetrek in gedachten. Toegespitst op het landschap doen Bruyns opmerkingen bij mij echter de vraag rijzen, of de collectreve beeldtaal van dit genre wellicht toch een subjectieve lezing van de voorstelling toestond. Werd er, door schilders en beschouwers, rekening gehouden met een subjecttef element in de receptie van de voorstelling? Werd dit subjectreve element zelfs verlangd en werd er door de schilder op geanticipeerd? Onderstaande interpretatie van Bruegels Krussdraging, gezien in het licht van de daaraan voorafgaande landschapstradit1e, geeft aanle1ding tot een bevestigend antwoord op deze vraag.

De algemene teneur van Bruegels voorstelling is duidelijk. Christus' lijden voor de mensherd staat in kontrast tot het gedrag van de vele honderden omstanders bi) z1yn laatste gang naar Golgotha. Compassie met Christus, een thema dat inherent is aan de laatmiddeleeuwse 1conografie van het 'Andachtsbild' van de Krusdraging, toont alleen een klene groep getrouwen aan de rand van de voorstelling: Maria en Johannes en de vrouwen die hen vergezellen. Verreweg de meeste anderen die in en rondom de krussdragingsstoet zijn weergegeven, laten allerle1 gedragingen en misdragingen zien, alleen geen compassie. Alle commentatoren zijn het er over eens, dat algemeen gesproken Bruegel een negatief beeld schetst van zijn t1jdgenoten, die hier als de (mede)voltrekkers van Christus' kruisigingsdood ziln weergegeven. Maar de interpretatorische problemen beginnen, wanneer men individuele detalls nader beziet. 


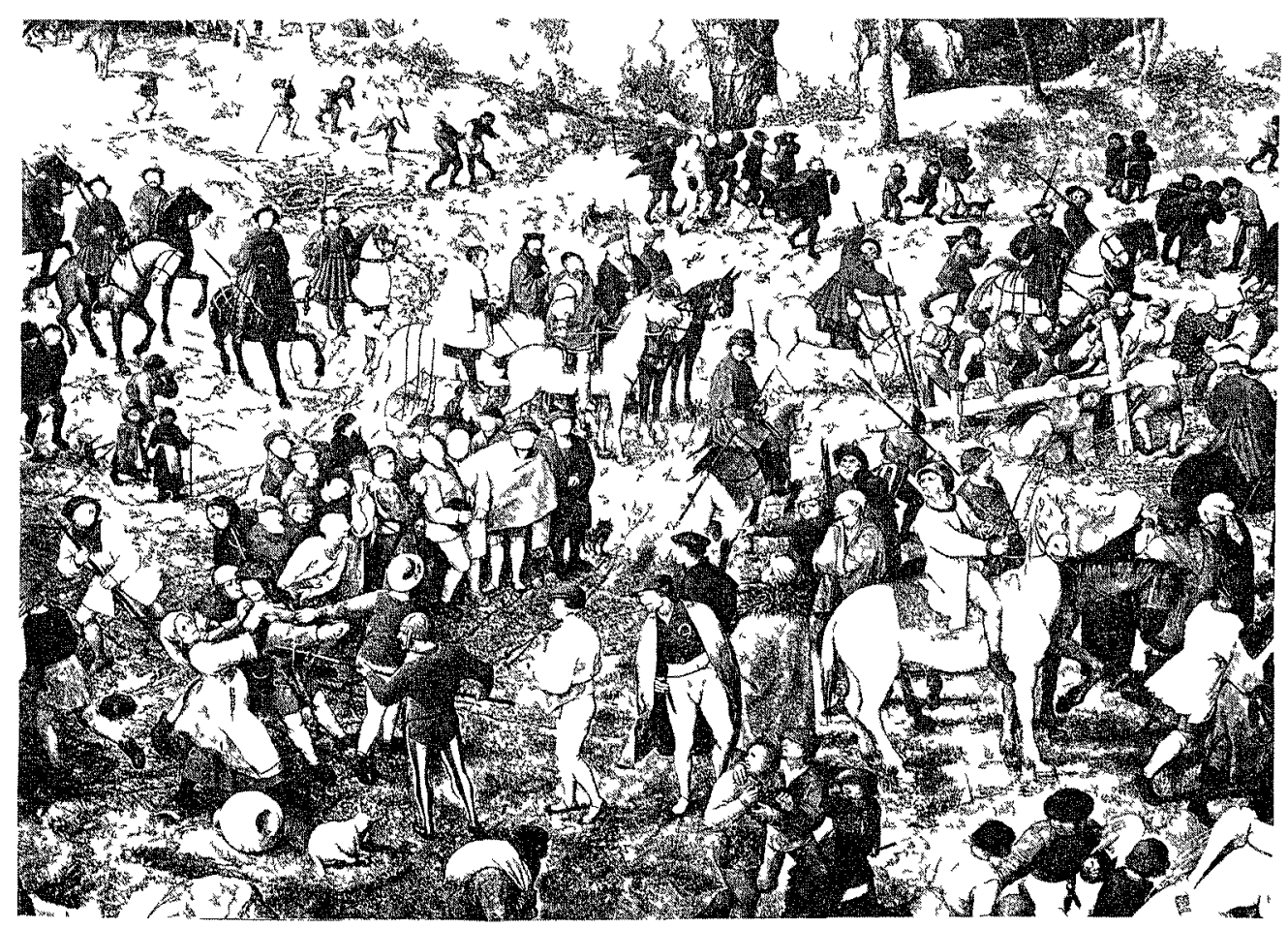

B1j sommige interpreten, vooral wanneer z1j het schılderij benaderen als het werk van een schilder die voor het eerst in de geschiedents van de westerse kunst het landschap als zelfstandige, esthetrsche kategorre expressie wist te verlenen, bestaat een durdelıke neiging maar helemaal niet af te dalen in het gekrioel van de honderden figuren en de voorstelling alleen in vogelvlucht te bek1fken. ${ }^{4}$ Maar de meeste kunsthistoric1 wagen zich toch aan een analyse van tenminste een aantal van de meest pregnante scènes, om aan de hand daarvan het menselı1k gedrag in Bruegels schilderif in generaliserende termen nader te karakteriseren. Zo is de nat vlak achter de onder de zwaarte van het kruss neergezegen Christus veelal beschouwd als de belichaming van de dwaasheid die de omstanders in het algemeen, en pars pro toto de hele menshe1d heeft bevangen (afb. 2). Dat wil zeggen, dat de figuur van de nar een verklarende waarde wordt toebedeeld voor het gedrag en de psych1sche gesteldherd van de rest van de omstanders: de scène met de nar fungeert als exempel-vertellıng. Evenzo is het gesteld met de vrouw van Simon van Cyrene, links op de voorgrond, die voor het oog van allerler nieuwsgierige, zich verkneukelende omstanders met alle macht probeert te verhinderen dat haar man - overeenkomstrg het bijbelse gegeven - gedwongen wordt om Christus bij het dragen van het kruis te helpen (afb. 3). Het fett dat zij ostentatief een rozenkrans draagt, wordt meestal uitgelegd als teken van geveinsde religiositeit en van cen schrijnend gebrek aan ware, innerlijke betrokkenhe1d met Christus Haar gedrag wordt vervolgens gezien als een katakteristiek van het gedrag van de mensheid in het algemeen, volgens de gedachte dat Bruegels schilderil in wezen een 'theatrum mundi' is dat een menselıke staalkaait toont van moreel verwerpelijk, verdorven, onverschillig, 'blind, bekrompen, zelfingenomen en hopeloos "profaan"' gedrag, alsook van minder ernstige menselıke zwakheden als dwaasherd en voze nueuwsgierigherd.'

De picturale anecdote rondom de vrouw van Simon van Cyrene 1 echter ook voor sommige commentatoren aanleiding geweest om positieve elementen in Bruegels visie op de mens te signaleren. Zo heeft Genaille, in een uitgebreide studie van de beeldtraditie die aan dit schilderij ten grondslag ligt, het tegenstribbelen van de 

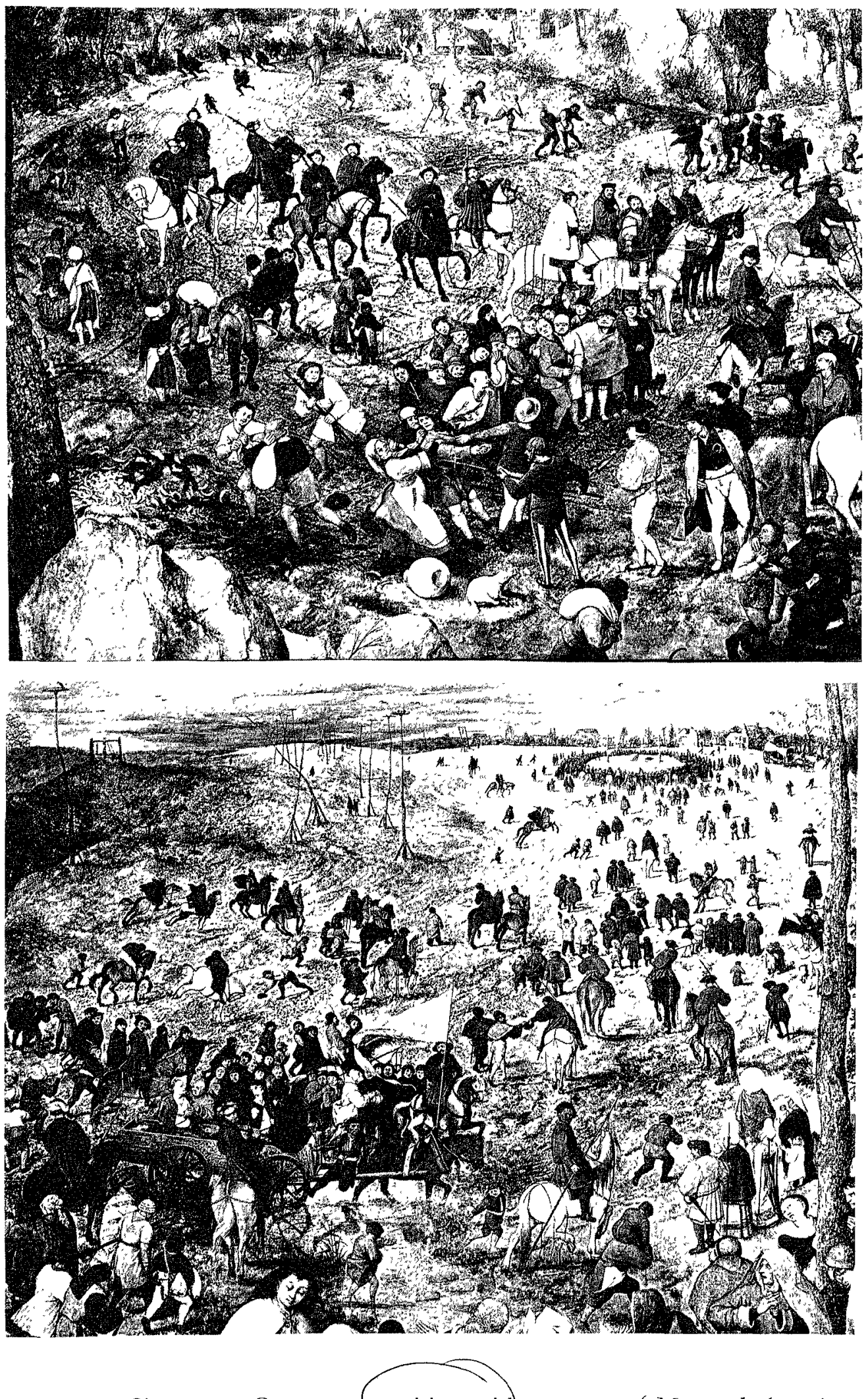

vrouw van Simon van Cyrene een positieve uitleg gegeven. ${ }^{6}$ Met onderkenning van de menselijke dwaasheid die het schilderij in het algemeen ten toon spreidt, ziet hij in Simon en zijn vrouw de onschuldige slachtoffers van het militaire geweld dat de machtigen hanteren om het doodvonnis ten uitvoer te laten brengen. Genaille komt tot deze uitleg door de positieve rol die hij de figuur van de boer toebedeelt in de beeldtaal van het zestiende-eeuwse landschap. In Bruegels schilderij, aldus Genaille, zijn Simon van Cyrene en zijn vrouw wcergegeven als boe- 
ren, simpele ziclen aan wie het religieuze drama geheel voorbijgaat en die net als de boeren in de Krusdragingslandschappen van Jan van Amstel, Herr1 met de Bles, Cornelis Massys en P1eter Aertsen slechts vreedzame bewerkers van het land zijn. Zij, en hun produkten, zijn geassocieerd met het landschap en de schoonherd daarvan, welke in kontrast staat tot de verschrikkingen van het religieuze drama. Ik kom nog terug op de rol van Simon van Cyrene en zijn vrouw, en van de boeren in deze landschappen in het algemeen, maar wijs er nu alleen op dat zelfs motieven met cen duidelijk herkenbare en aan de hand van schriftelijke bronnen te toetsen anecdote niet eenduidig blijken te zijn - althans net voor moderne interpreten. Nog problematischer is de duiding van de vele motieven en scènes waarvan het verhalende gehalte minder geprononceerd is en waarvoor elke literaire bron of picturaal voorbeeld lijkt te ontbreken. Deze zijn steeds subjectıef-psychologiserend en -'hinein-1nterpretierend' uitgelegd. Dat is bijvoorbeeld het geval met een groep 'humoristische' en 'speelse' motteven. Zo noemt Demus de voerman van de , paard-en-wagen die de met Christus te kruisigen moordenaars vervoert, een 'komisch detatl', omdat hi1, zittend op de dissel van de wagen, zijn benen opgetrokken houdt bij het passeren van een modderige poel (afb.4).7 De jongens die, links op de achtergrond, over waterplassen springen of de man ver op de achtergrond aan de andere zijde van de kompositie die de baret van zijn kind heeft afgenomen en buiten diens bereik in de lucht houdt (afb.4), heten 'speels'. De fysionomie van vele omstanders in de stoet is als 'burlesk' of 'realistisch-komisch' omschreven; en 'triviaal' zijn details genoemd als de muts van een man rechts op de achtergrond, die door een hefrige wind lijkt te zijn afgewaa1d. ${ }^{8}$

Voor sommige kunsthistoric1 - en hier is een evidente parallel met de negatieve reacties op Bruyns these over het allegorisch-moraliserende gehalte van het I 7 deeeuwse landschap ${ }^{2}$ - geven deze laatstgenoemde motieven aanleiding om een al te ver doorgevoerde moraliserende uitleg te kapittelen. Bruegel is in hun ogen veel minder zwaar op de hand dan vele van z11n moderne uitleggers (Stridbeck b) jvoorbeeld spreekt van de 'moraalleer' van het schilder1j). ${ }^{\circ} \mathrm{H}_{11}$ beeldt veeleet het 'al te menselıke' en het " onschuldige karakter" van de onutroetbate dwaasheden van de menselıjke menagerie' uit. 'Knapen moeten zich vermaken met het springen over waterplassen, en honden moeten (...) kunnen rondhollen zonder dat iconologen reeds "allegorie" of "satıre" gaan roepen."

Wie gaat er nu te ver: de 'die-hard'-1conoloog (die vaak wordt verweten zelf moralist te zijn) of de na-verteller, die individualıstısche psychologiserende kunstbeschouwing inzet. Mijn stelling 1s, dat de wens dit dilemma op te lossen anachronistisch 1s, en dat het dilemma zelf - dat niet alleen hier speelt maar ook in de hele discussie romdom de semantiek van de zeventiende-eeuwse landschap- en genre-schulderkunst - de kern raakt van de zestıende-eeuwse receptie en de 'boodschap' vaı Bruegels schilderij. Ik wil hiermee niet het relatıvisme huldıgen dat de postmodernistısche navelstaar-kunstgeschedenıs (de 'new art history') van Norman Bryson en zijn navolgelingen kenmerkt. ${ }^{2}$ Ik meen dan ook dat de historische onjuistheid, dat wil Leggen het anachronisme van de vergoelijkende le 2 ing van het 'al te menselijke' in Bruegels schilderi1, kan worden aangetoond wanneer men het trad1t1onele motievenrepertorre, en dus de 'collectreve beeldtaal' waarvan Bruegel gebruik heeft gemaakt, meer bij de u1tleg betrekt. Maar evenzeer denk $1 \mathrm{k}$ dat het subjectieve interpretatie-element verankerd is in de beeldtaal zelf.

Om deze stelling te adstrueren wil ik kort recapituleren wat $1 \mathrm{k}$ in een tweetal studies over de iconografie van het vroeg-zestiende-eeuwse landschap te berde heb gebracht. " In een aantal landschappen van de belangtılsste vertegenwoordigers van dit genre in de perıode is i 5- is 65, Joachım Patınır, Herrı met de Bles en Jan van Amstel (de Brunswijkse Monogrammist), bepaalt een antıthese de iconografische grondstruktuur van de voorstelling. Bip Patinir is dit een tegenstelling tussen 


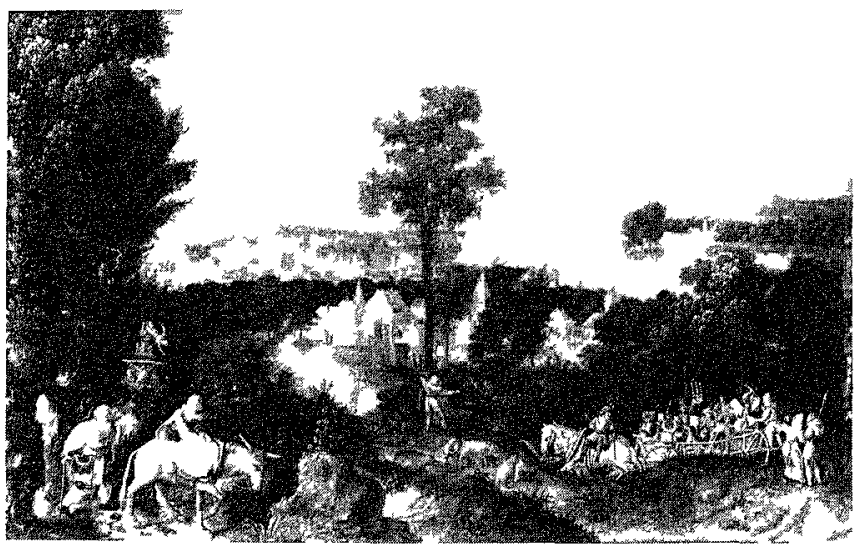

Herri met De Bles I andebap met de lucbt naar I sypte Kopenhasen Statcns Muscum for Kunst.

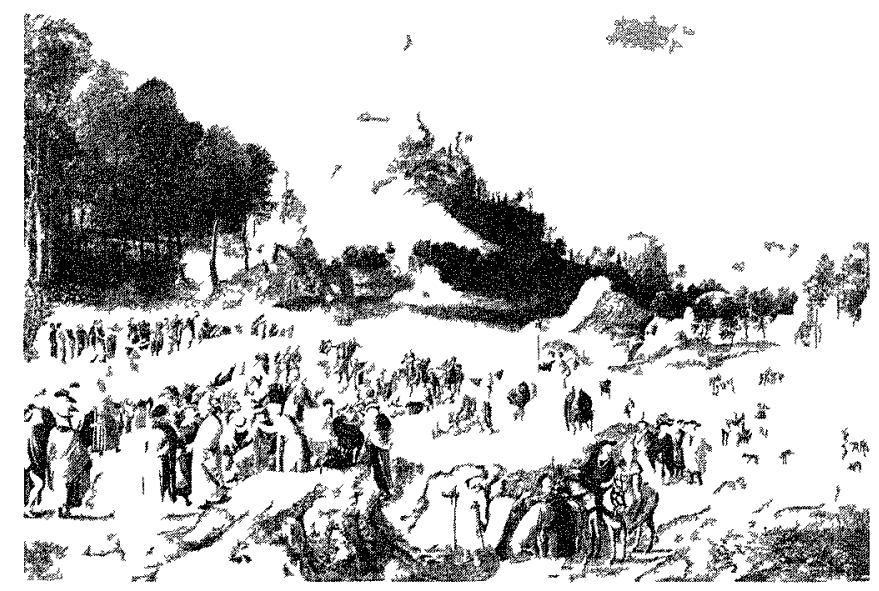

Hcrri mot de Blcs $T$ andschap met de Predekeng van Jelannes vcrbliffplazts onbekcred foto $\wedge \mathrm{C} \mathrm{J}$ Brusscl

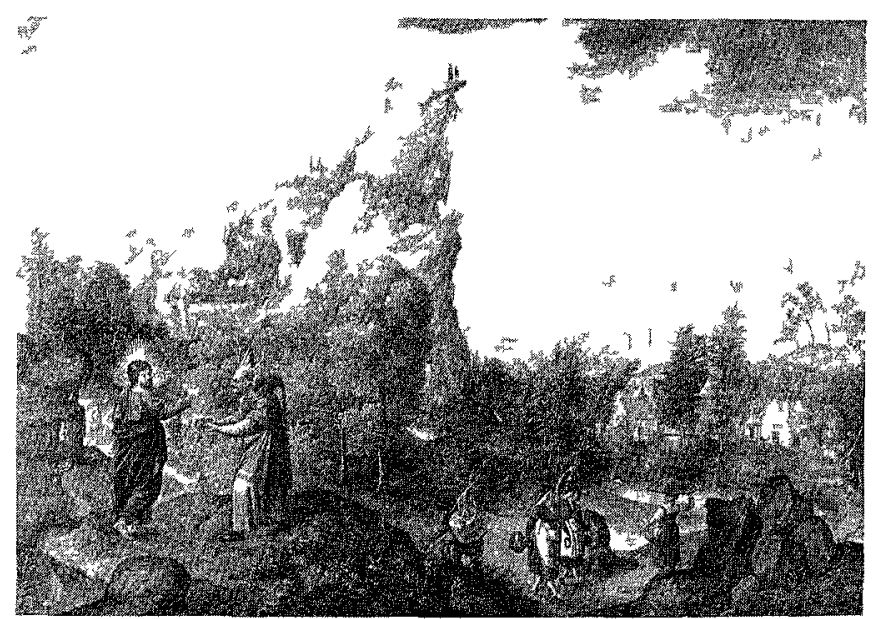

6

Herrı met dc Bles I andschap) met de Vorzoekensen a an (brestus particuluc re vcrameling

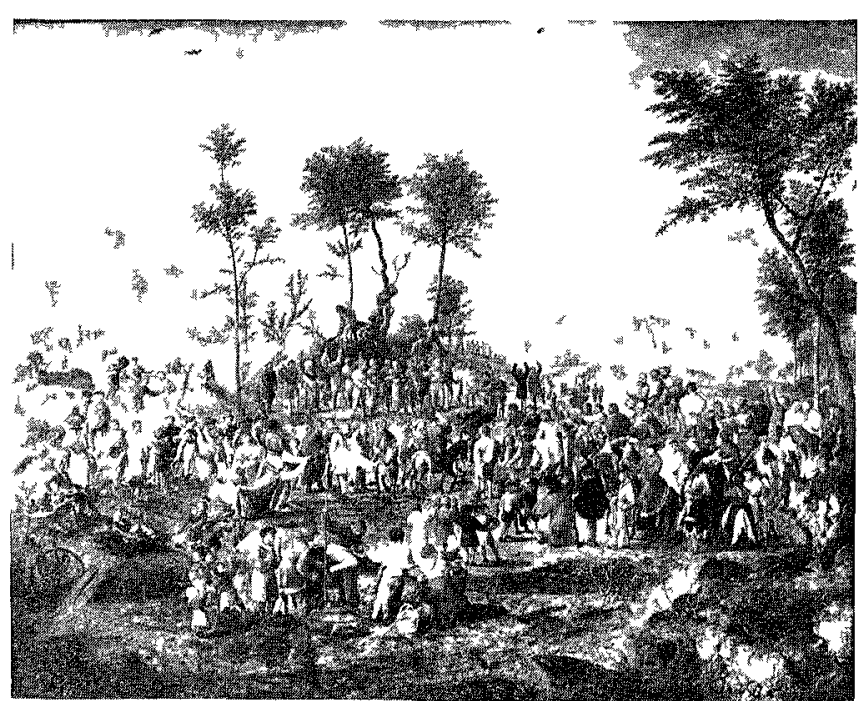

Jan van Amstel I andsch pp mot do Inlocbt in Jeruqalem Stuttgart Statsgaleric

de exemplarische levenspelgrim Jesus, of een hellige die /1jn weg (het 'smalle pad') tracht te vinden door de rondige wereld, en mensen die het gemakkelijke, 'brede pad' begaan, aardse goederen vergaren cn 7 ich overgeven aan wereldse beslommeringen Het figurale, meestal legendarre element van de voorstelling en het landschap relf participeren met allerlei detals in de utbeelding van de levenspclgrimage allegorie In een reeks schilderijen die wordt toegcschreven aan Herr1 met de Bles en Jan van Amstel, is dit antithetische principe voortgezet, echter niet zoreer in het landschap elf als wel in de figurale voorstelling Nu is het veelal een neuw testamentisch verhaal voornameljk het leven van $\mathrm{jc}$ cus betref fende dat het voorbeeld geeft van een God welgevallige levenswandel, boeren daarentegen exemplifieren de hell loze bekommernis om aardse goederen De beeldtaal van de/e schilderijen is, net als die van Patınırs landschappen, geworteld in de traditie van de laatmiddeleeuwse allegorese en dient primair de verbeelding van religıeus morele waarden, roals de navolging van Christus' leven cn li, den in 


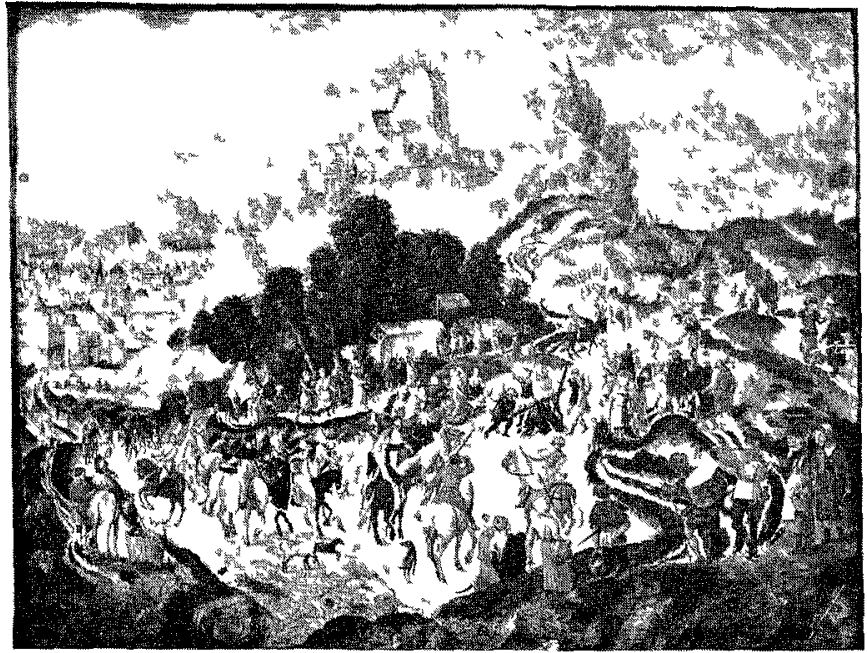

Herri met de Bles, Landschap met de Kruzsdraging, Rome, Galleria Doria Pamphili

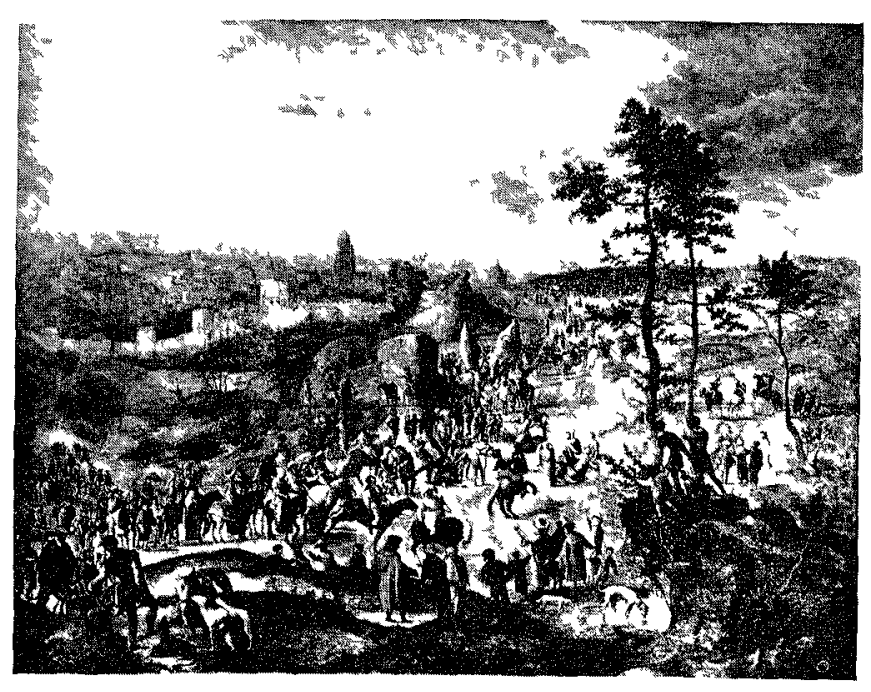

10

Tan van $\Lambda$ mstel, Landscbap met de Kruschagang, Parujs, Louvre

het eigen leven van de zestrende-eeuwer. Hier hebben we de beeldtaal waar Bruyn het over heeft. Landschappen met de Krusdraging die de direkte voorgangers van Bruegels versie in Wenen vormen, en waaraan Bruegel aantoonbaar bepaalde verhalende detalls heeft ontleend, behoren tot deze groep, evenals landschappen met thema's als de Vlucht naar Egypte, de Verzoekingen van Christus in de woestıjn, de Prediking van Johannes de Doper en de Intocht in Jeruzalem (afb. . 8). De wisseling - binnen deze groep schilderijen als geheel - van steeds weer andere religteuze protagontsten, terwil het motief van de boeren op weg naar de markt telkens herhaald wordt, toont aan dat de desbetreffende schilders de figurale voorstelling steeds hebben geconcipteerd volgens een programmatische tegenstelling tussen type en antitype, tussen exempla van goed en slecht gedrag Terwill het religieuze type verwisselbaar is, blifft het boeren-antitype constant. Dit betekent dat wanneer w1] de iconografische antecedenten van Bruegels Krussdraging proberen te traceren, wil nuet alleen - zoals tot nog toe 1 gedaan $^{14}$ - moeten kijken naar landschappen met hetzelfde religieuze thema, maar ook naar andere landschappen met een verwante iconografische grondstruktuur.

Dit heeft allereerst tot gevolg, dat wi) het motref van de ter markt gaande boeren in Bruegels schilderij op hun juiste, dat wil zeggen traditionele allegorische waarde kunnen schatten Dit mottef heeft zijn oorsprong in een verloren gegane inventie van Jan van Eyck, waarvan een zestiende-ceuws schilderil met de Krusdraging in Budapest vermoedelıjk een redelık getrouwe weergave is. Hier vindt men voor het eerst boeren die op weg zinn naar de markt en die, met de produkten van het veld aan de arm en op het hoofd, de Krusdraging gadeslaan ${ }^{15}$ Het is onduidelıjk of deze boeren (en de begeleidende pelgrims die eveneens rustig langs de kant van de weg lijken te wachten tot de stoet is gepasseerd) reeds bij Van Eyck een negatieve betekenis hebben. Voor hun rol als antitype in de daaruit voortvloetende zestiende-eeuwse landschapstraditie zijn wel aanwijzingen, ook formele ${ }^{\text {i }}$ 'Typerend voor deze traditie is dat boeren niet alleen zijn voorgesteld als de observanten van de lijdende Christus die door het schouwspel onaangedaan blijven (afb 9), maar ook letterlık als de antıpoden van Christus zijn weergegeven, aangezıen zij de weg die Christus gaat in omgekeerde richting bewandelen. In Jan van Amstels Kruisdraging in Parijs (afb. 10) ziet men op de achtergtond dit motief, waarvan de negatieve inhoudelijke implicaties nog eens zijn onderstreept doordat de boeren een hootwagen begeleiden. ${ }^{17}$ In een Kruisdraging van Van Amstel, voorheen in 


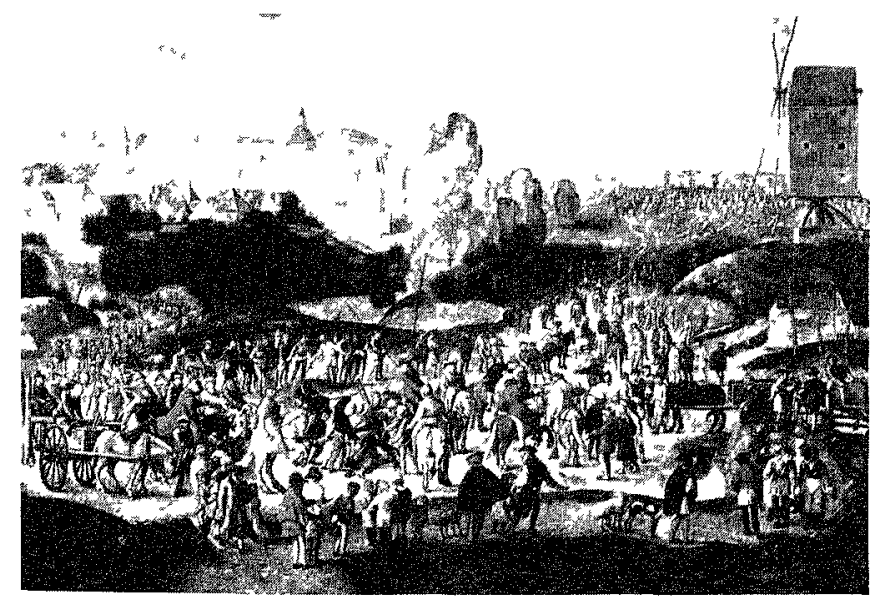

I I

Jan van Amstel, I.andschap met de Krutsdragzng, (voorhecn) Amsterdam, ver/ameling $P$ de Boer

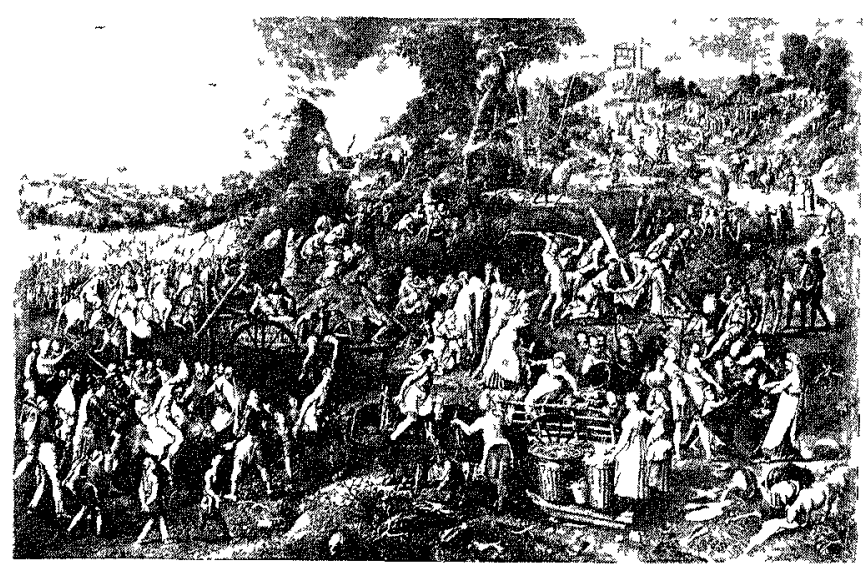

12

Preter Acrtsen, Landschap met de Krnidraging, Beilyn, Ka1scr Friedruch Muscum (verloren gegaan)

Amsterdam (afb. I I), komt het haaksstaan van het gedrag van de boeren op dat van Christus visueel tot uitdrukking in de richting van de paard-en-wagen die door boeren dwars door de kruisdragingsstoet wordt heengeleid. Pieter Aertsen heeft dit motief overgenomen in een verloren gegaan schilderij in Berlijn (gedat. I 5 s; afb. I 2). Rechts op de achtergrond kruist een boer met zijn paard en wagen de Kruisweg; op de voorgrond wacht een andere groep boeren, vergezeld van paarden, een slede en een kar die beladen zijn met allerle1 marktwaar, tot de krusdragingsstoet is gepasseerd en zij hun weg in tegengestelde richting kunnen vervolgen. Vlak naast deze groep is een scène met Simon van Cyrene en zijn tegenstribbelende vrouw weergegeven die overeenkomt met Bruegels anecdote. Uit hun (antiquiserende) kleding is niet direkt op te maken dat deze bijbelse personages boeren zijn, maar indirekt blijkt dit uit enkele nevenmotieven: een mand met marktwaar direct achter hen, waaruit honden de inhoud roven, alsook een omgevallen melkkan.

Bruegel heeft in elk geval uit Aertsens schilderij (of een ander, vergelijkbaar voorbeeld) de conclusie getrokken dat de rol van Simon van Cyrene's vrouw als dwarsligger van Christus en zijn lijdensweg z.1chtbaar gemaakt kon worden door haar en haar man weer te geven als boeren die op weg zijn naar de markt, conform de rol van deze personages als antitypen in de voorafgaande landschapstraditie. Het lijdt mijns inziens dan ook geen twijfel dat deze groep in het licht van deze traditie 'in malo' moet worden uitgelegd, en niet vrijelijk als komische of neutrale 'genre'-figuren moet worden geinterpreteerd. ${ }^{18}$ Een aanwijzing hiervoor te meer is dat Bruegel ook het standaard-motief van de ter markt gaande boeren die in tegenovergestelde richting van Christus gaan, ut deze traditie heeft overgenomen en niet ver van de scène met Simon van Cyrene en zijn vrouw heeft weergegeven. Ik leg zoveel nadruk op deze motieven, omdat daar nog een andere conclusie aan te verbinden is. Als Bruegels schilderij geworteld is in de antithetische iconografie van deze landschapstraditie, kunnen ook andere scènes in dit kader worden bezien. Dit kan bijvoorbeeld met de ruiters vlak achter de neergezegen Christus, die in zestiende-ceuwse kledij zijn gehuld en het rechterlijke en militaire gezag representeren. Zij verbeelden de Joodse en heidense machthebbers die volgens het bijbelverhaal verantwoordelijk zijn voor Christus' kruisiging, en die ook reeds in de op Van Eyck teruggaande Kruisdraging pal achter Jezus zijn weergegeven. Het zijn, met andere woorden, negatieve personages, hier bij Bruegel, maar ook elders in de beeldtraditie van het zestrende-eeuwse landschap. In Jan van Amstels Intocht in 


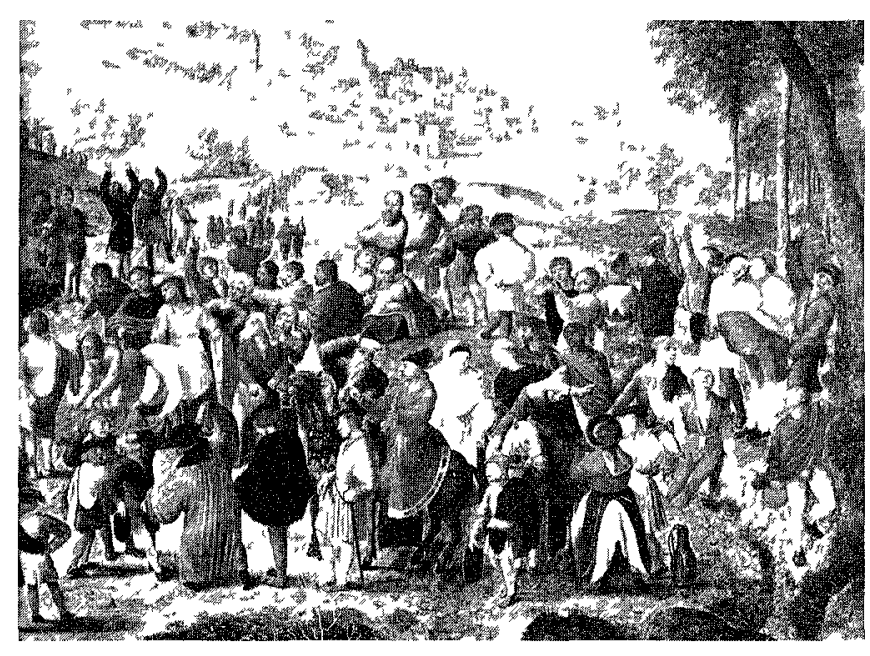

I 3

Jan van $A$ mstcl, detall van afb 8

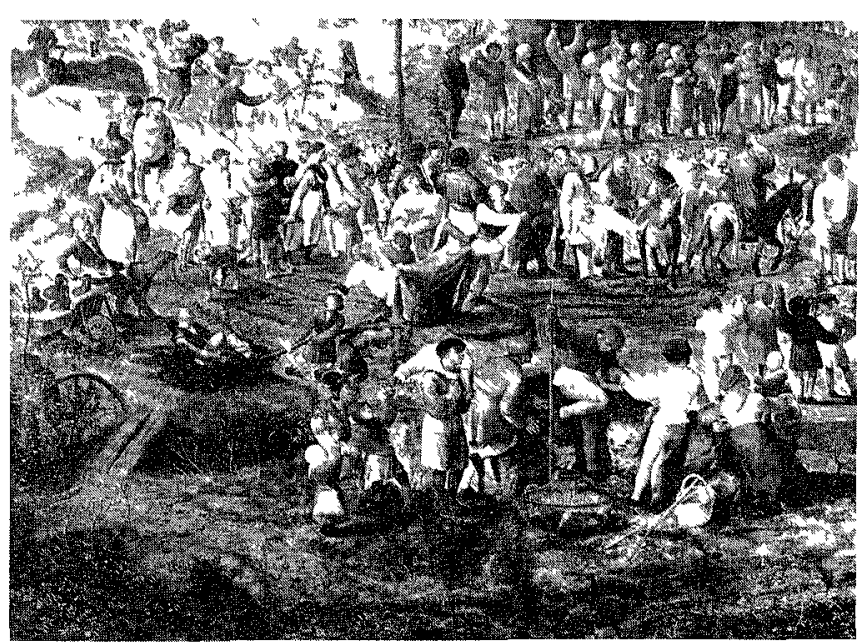

Jan van Amstel, detall van afb 8

Jeruqalem (afb. 8; I3) zien wij vergelijkbare hoogwaardigheisbekleders te paard door hun kleding deels als vertegenwoordigers van het Joodse geloof, deels als zcstiende-eeuwse religieuzen gekenmerkt - Christus afkeurend gadeslaan. Hier komen wij een motief op het spoor dat als een rode draad door de hele voorstelling heen loopt en dat tevens een grondthema is van Bruegels Krusdraging: het tegendeel doen van de 'imitatio Christi', of meer algemeen, het tegendeel doen van datgene wat men van een ethisch handelend christen mag verwachten. In Jan van Amstels schilderij is dit allereerst zichtbaar gemaakt in een magistraat, direkt vóór de beschreven ruitergroep, die met een jongen op de vuist gaat. Ook de ruiters doen het tegendeel van wat zij zouden moeten doen: deelnemen aan het eerbetoon dat het volk Jezus betuigt, hun kleren uitdoen en ze op de grond leggen (Mattheus 21: I-9; verg. Lukas 19:36-40). Van Amstels schilderij biedt nog andere scènes die dit grond thema illustreren en het loont de mocite deze in enig detail te analyseren, omdat daarmee een verteltechniek en een receptiewijze zijn gemoeid die vooruitlopen op de beeldtaal van Bruegels Kruisdraging. ${ }^{.9}$

Middenin de stoet die Christus op zijn tocht naar Jeruzalem vergezelt, ziet men een groep mannen die met elkaar vechten om het bezit van de kleren die zij zoëven hadden neergelegd uit eerbetoon voor Jezus (afb. $\mathrm{r}_{4}$ ). Ook andere omstanders geven er blijk van het tegendeel te doen van wat men van de navolgers van Christus zou verwachten: een man geeft het jong van de ezelin waarop Jezus rijdt een trap, en meer naar links kan men een man ontwaren die heimelijk de beurs snijdt van zijn metgezel. Is een negatieve uitleg van deze details onontkoombaar, ze roepen ook de vraag op of het ogenschijnlijk speelse motief van de jongens dicht in de buurt van de vechtende mannen - die sleetje rijden met een van de afgeslagen boomtakken, wel zo onschuldig is. Niet alleen wordt hier speels voortgeborduurd op de bijbeltekst die vertelt dat de schare (uit eerbetoon) naast kleten ook boomtakken voor Christus op de weg spreidt (Mattheus 2 1:8), maar men moet ook concluderen, dat een voorwerp dat zoëven gebru1kt is als teken van eerbetoon, nu door het slijk wordt gehaald.

Het is nuttig even stil te staan bij de negatieve lezing waartoe dit motief bij nadere beschouwing uitnodigt, omdat de interpretatie-problemen die hiermee gemoeid zijn, ook spelen bij Bruegels Kruisdraging. Voor zover ik heb kunnen nagaan zijn er geen teksten die als voorbeeld hebben gediend voor Van Amstels voortborduren op het bijbelse motief van de tak en de kleren. Het lijkt als beeldvertelling een eigen inventie van de schilder te zijn geweest. Het principe dat hij daarbij heeft gehan- 
teerd, is dat van de 'amplificatıe' van het verhalende gegeven. Deze uitbreiding lijkt geent te zijn op de antithese tussen bijbelse protagonist en zestiende-eeuwse 'aardse' zondige mens, die méér landschappen uit deze tıjd te zien geven. Maar terwijl men deze iconografische traditie kan aanvoeren als reden om het sleetje rijden in negatreve zin te duiden, is zo'n negatreve duiding nret vanzelfsprekend. Het is immers niet zo, dat het gedrag van álle omstanders afkeurenswaardig 1 , want overeenkomstig het bijbelverhaal zijn er ook velen die zich overgeven aan het toejuichen van hun koning. Aan de orde is dus nuet het laakbare gedrag van de menshe1d in haar geheel, of van de menselıje natuur als zodanı, maar het laakbare, dan wel loffelıke gedrag van individuele personen. Het is aan de beschouwer om te beoordelen, in welke gevallen er sprake is van afkeurenswaardig gedrag, en in welke gevallen niet, en dit geldt ook voor de spelende jongens. De nabijheid van deze jongens tot de vechtende mannen; het fert dat het in berde scènes gaat om handelingen rondom een schriftuurlyjk motief; de overeenkomst met andere scènes die handelingen tonen die het tegendeel zijn van wat men zou verwachten, en dus het vermoeden dat het hier om een grondthema van de voorstelling gaat - dit alles zijn argumenten voor een negatieve durding, maar absulute zekerherd valt niet te verkrijgen.

We raken met zulke onzekerheden niet alleen het probleem van de iconologische analyse - wanneer kan een bepaalde uitleg nog verantwoord worden genoemd maar ook de historische, dat wil zeggen de door de schilder beoogde strekking van de voorstellıng. Er zijn ook andere scènes in deze voorstelling die welıswaar een bepaald verhalend gehalte lijken te bezitten maar waarvan de specifieke zin ook na enige overdenking niet eenduidig vast te stellen is. Zo bevinden zich onder de toeschouwers aan de uiterste rechterzijde van de voorstellıng enkele mensen die met elkaar druk in gesprek zijn (afb. I3). Het gaat hier niet om een motief waaraan geen bijzonder belang hoeft te worden gehecht, omdat de schilder b1j zijn weergave van een schare mensen (een bijbels gegeven) nu eenmaal een zekere anecdotiek moet aanwenden om afwisseling en levendigheid te beretken. Hier wordt gediscussieerd, en wel zo nadrukkel1jk, dat het discussieren als het ware gethematiseerd wordt. Een op de grond gezeten man heeft, met zijn rechterhand gesticulerend, z1jn hoofd opgeheven naar een andere, wat hoger geposteerde man, die zich naar z1jn metgezel vooroverbuigt om hem goed te kunnen verstaan (de persoon achter hem heeft een arm opgeheven en de mond opengesperd: het geroep is dus net van de lucht). Wat hier bediscussieerd wordt is voor de beschouwer van het schilderi1 niet duidelijk; toch vraagt deze nadrukkelijk in beeld gebrachte discussie evenzeer als de scène met de spelende jongens om een specifieke uitleg.

Men kan dit interpretatie-probleem slechts oplossen - en $1 \mathrm{k}$ meen, dat het in de bedoeling van de schilder heeft gelegen om het zo op te lossen - langs de weg van een subjectieve 'inlezing' door de recipient van een bepaalde betekenis in samenhang met de thematiek van de overige scènes. Deze samenhang is niet in haar totaliteit 'gegeven' maar moet al kyjkend en interpreterend in de geest van de beschouwer geconstrueerd worden. De vootstelling-biedt daartoe wel een paar markante bouwstenen en de contouren van een('bouwplan': dnkele duidelijk negatieve en enkele positieve handelingen die een antithetische grondstruktuur zichtbaar maken. Maat het is aan de beschouwer om het bouwsel van zijn interpretatie op basis van dit grondplan op te richten en de verschillende scènes binnen deze samenhang een plaats te geven. Het is geenszins een uitzonderlıjke taak waarvoor de beschouwer zich hier gesteld ziet, want de figurale voorstelling in het landschap sinds Patınır is steeds ingericht ten behoeve van de constructıe in de geest van de beschouwer van een verhalende en thematısche samenhang uit verschillende af zonderlijke scènes (vaak verschillende episodes uit het levensverhaal van de protagonist) die her en der over het landschap zijn verspreid. ${ }^{20}$ De mentale activiteit die 
de interpretatie kan deze scènes met zich mee brengt is eetder te vergelijken met een meditatieproces tijdens hetwelk verhaal-brokken tot een geheel worden aanééngesmeed, dan met een lezıng van een episch uitgesponnen verhaal die getrouw de letter van de tekst volgt Niet alleen voegt de beschouwer in gedachten meer verhaal-elementen toe dan er in de voorstelling feitelijk zichtbaar z1jn, maar ook houdt dit k11k-en overdenkingsproces qualitate qua een dosis subject1eve project1e en aanvulling van het beeldende gegeven in.

Op deze wijze heb ik de scène met de spelende jongens benaderd en kan men ook de scène interpreteren van de boeren met hun marktwaar die, overeenkomstig de landschapstraditie waartoe Van Amstels Intocht behoort, op enige afstand (achter een greppel) het bijbelse gebeuren gadeslaan Eén van de boeren draagt een lam, waarvan de poten samengebonden zijn, over zijn schouder. Dit lam tracht wat blaadjes van een tak te eten die het aangere1kt krijgt door enkele kleine (boeren-) kinderen. Een wat oudere jongen lijkt dit weer te willen verhinderen, getuige de armbeweging waarmee hij het kind met de blaadjes naar achteren trekt en de muts in zijn andere hand waarmee hij een afwerend gebaar naar het lam maakt. Onbedu1dende anecdotiek, speelse amplificat1e? Zelfs wanneer men niet onderkent (of erkent) dat boeren personages zijn waarvan de negatieve associaties standaard waren en zelfs wanneer men een uitleg van het lam als een symbool voor Christus (het lam Gods) als over-1nterpretatie terzijde legt, dan nog is het tegenovergestelde gedrag van de hinderende jongen en het kind met de tak evident In samenhang met en parallel aan de overige handelingen met de takken en de kleren kan men deze scène een heel specifieke duiding geven. Deze scène laat dan zien, dat er 'goede' kinderen zijn die mededogen hebben, alsook 'slechte', meedogenloze kinderen, zoals er ware volgelingen van Christus zijn die hem toejuichen en eer bewijzen, maar ook huichelaars, dieven en hebzuchtigen: 'navolgers van Christus' die zıjn naam door het slijk halen. Een bijzondere pointe kt1jgt deze kleine scène wanneer men de Christus-assocratie, respectievelijk ant1-Christus-associatie van het lam en de boer hierbij verdisconteert. Terwijl boeren tradit1e-getrouw negatieve personages zijn die onaangedaan blijven bij het zien van Christus' lıdensweg, blyjken er toch ook sommigen onder hen te zijn (z1j het dat het kinderen zijn) die mededogen met Christus hebben. Kort en goed: de sche1dingslipn tussen 'goeden' en 'slechten' loopt dwars door de ogenschijnlık tegengestelde kampen van navolgers en antipoden van Christus heen.

Langs deze weg van de gestuurde maar tevens subjectıve 'inlezing' van een specifieke zin in ogenschijnlijk onbeduidende anecdotische details knijgt ook het onopvallende motief relief van de hand die Christus tegen ziln ogen gedrukt houdt (afb. 14) Dit motief kan gerelateerd worden aan een passage bij Lucas (19:4I-42): 'En toen $\mathrm{H}_{11}$ nog dichterbij gekomen was en de stad zag, weende $\mathrm{H}_{11}$ over haar, en zeide: Och, of gij ook op dezen dag verstondt wat tot uw vrede dient, maar thans is het verborgen voor uw ogen.' Ik zal de argumenten die $1 \mathrm{k}$. elders heb genoemd om aannemelijk te maken dat het hier om een significant detall gaat, net herhalen. ${ }^{2 r}$ Kern 1s, dat dit motief aanslutt bij de bijbelse thematrek van een hele reeks landschappen uit dezelfde groep (andere werken van Van Amstel incluis), waarin de tegenstelling tussen uiterlıjk zien maar innerlijk blind blijven voor Christus' boodschap versus innerl1jk 'zien' en Christus navolgen centraal staat. De boeren in deze landschappen (waaronder die met de Krussdraging die hierboven zijn genoemd) zijn degenen die uiterlijk zien maar innerlijk blind en onbewogen blijven, en soms ook uiterlijk 'blind' zijn, wanneer zij het hoofd nadrukkelijk van Christus afgewend houden en naar de grond kijken, zoals in een schilderij van Jan van Amstel in Basel en in een schilderij van Pieter Aertsen in Antwerpen (afb. I 5, i6). B1] de vraag wie dan wel de innerlipk ziende 1s, speelt de beschouwer een centrale rol. Ik heb er althans voor gepleit, bepaalde formele eigenaardigheden, zoals de zeer kleine af- 


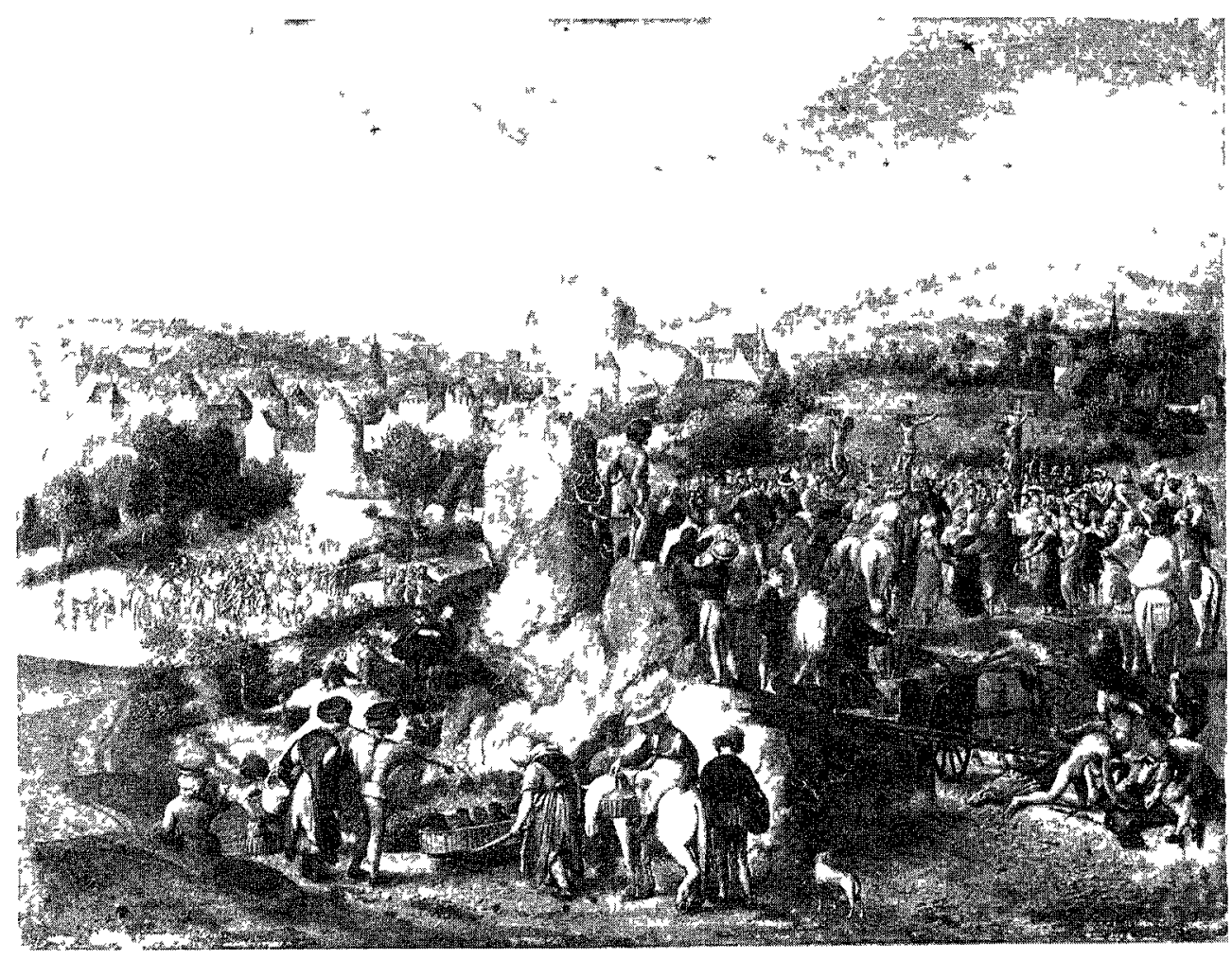

metingen van de verschillende scènes die het desbetreffende bijbelverhaal uitbeelden, te zien als een middel om de beschouwer persoonlijk - visueel en mentaal te betreklsen bij de strekking van de voorstelling. Heeft de beschouwer letterlijk en figuurlijk oog voor wat er gaande is in de wereld; doorziet hij zelf wel wie Jezus is en wat zijn boodschap is? Heeft hij werkelijk inzicht in - of is hij veeleer blind voor - het allooi van zijn eigen moraal: dat is ook de vraag die Jezus' handgebaar in Jan van Amstels Intocht in Jeruqalem oproept. Maar dat is niet alleen een vraag voor de toeschouwers van de intocht in de voorstelling maar ook voor de beschouwer van het schilderij. Alleen een goede verstaander kan ook de stemmen horen van de discussiërende mannen aan de rechter zijde van de voorstelling en het onderwerp van bun gesprek peilen: $z 1 j$ laten zien dat de persoonlijke betrokkenheid bij Christus en de moraal van elk mens - acteur én toeschouwer - onderwerp van discussie zijn, niet een vast gegeven.

Voordat wij terugkeren tot Bruegels Kruisdraging, wil ik enkele karakteristieken van Jan van Amstels beeldtaal, die uit bovenstaande interpretatie naar voren komen, nog even op een rij zetten. Bij de beschouwer wordt een interesse verondersteld voor het individuele detail, ook het ogenschijnlijk meest triviale. Juist in onbeduidende handelingen ligt een pointe die de strekking van de voorstelling in haar sern raakt. De speelshend van bepaalde motieven wordt door deze lezing niet 'weg-gemoralıseerd', maar krijgt, gezien in het licht van de iconografische (antithetische) grondstruktuur van de voorstelling in zijn geheel, een schrijnend-pregnante zeggingskracht. Het uitgangspunt voor deze uitleg is, dat alle indivicuele scènes en motreven in één samenhang geduid kunnen worden, een samenhang die niet bij voorbaat gegeven is, maar al kijkend en overdenkend door de beschouwer moct worden geconstrueerd. Ruimtelijke nabijheid en motief-herhaling zijn de stijlmiddelen waarmee de voorstelling de interpteet te hulp komt. 'Over-interpretatie' in de zin van: gewicht geven aan kleine ogenschijnlijk oppervlakkıge vertelsels, is precies de receptie-houding die van de beschouwer wordt verlangd. Het subjectieve oordeel van de beschouwer bij zijn weging van de bedoelingen van een 
16

Pieter Neitsen, Landschap mot de Krusdraging, Antwerpen, Museum voor Schonc Kunsten

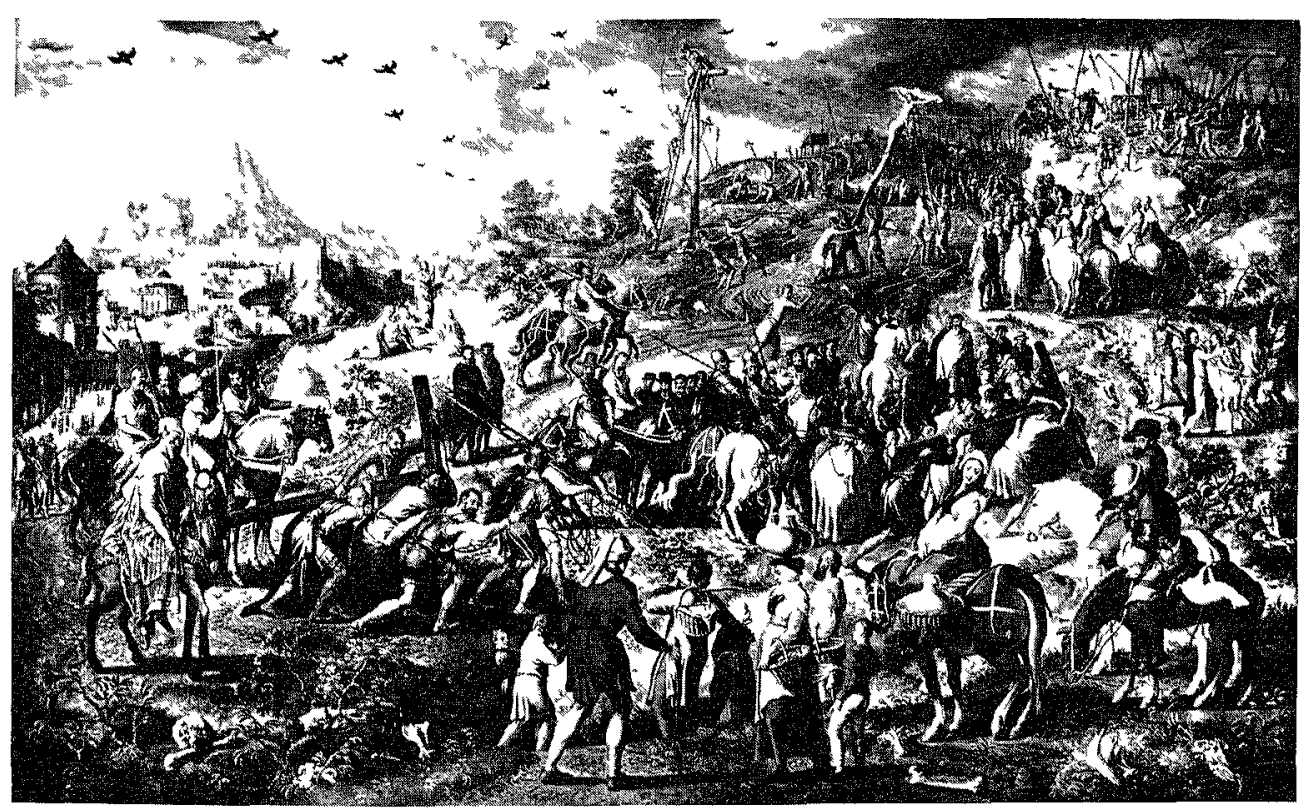

bepaalde scène is essentieel, maar is wel verankerd in en gerıcht op vaste morele kategorteèn. De onzekerheid ten aanzien van de vraag of men met een bepaalde interpretatie 'goed zit' (en 'goed ziet'), is niet alleen te beschouwen als een probleem voor de twintigste-eeuwse iconoloog, maar is inherent aan de voorstelling zelf en moet als een door de schilder geintendeerd, positief element in de receptic van de voorstelling worden beoordeeld.

Bruegels Kruisdraging moet mijns inziens in het licht van de antithetische iconografie van het figurale voorstellingselement in de voorafgaande landschapstraditie en speciaal in het licht van het grondthema en de verteltechniek van Jan van Amstels Intocbt in Jeruzalem worden bezien. Niet alleen kan de tegenstribbelende vrouw van Simon van Cyrene nu op zijn juiste waarde worden geschat, maar ook andere 'humoristische', speelse en triviale motieven. De man die bij het oversteken van een modderig water, zittend op de dissel van een paard-en-wagen, zijn benen optrekt (afb. 4), levert juist als 'humoristisch motief' in de samenhang van de hele passie-vertelling een navrante pointe op. ${ }^{22}$ Deze man makt aanschouwelijk hetgeen ook de moordenaars ten deel valt die in de wagen zijn gezeten: droge voeten. Dit anecdotische deta1, dat nog eens is benadrult door de stromen modder die van de wielen afdruipen, makkt de scène in de kar, waar twee vertegenwoordigers van de kerk - een fransıscaanse en cen dominıcaanse monnik - de moordenaars bijstaan, ontvankelijk voor een heel specifieke lezing, mits men deze scène in relatie zlet tot Christus. Terwijl de moordenaars lichamelijke en geestelijke bijstand krijgen op hun moeilijke tocht naar de plaats van hun terechtstelling, wordt Christus dergelijke bijstand onthouden. Integendeel, gesard door zijn belagers moet hij zich aanstonds wél door het smerige water slepen. Deze contrasterende lezing kan zonder meer uit de voorstelling zelf worden opgemaakt, maar er is in dit geval ook een iconografische traditie die haar ondersteunt. In de laatmiddeleeuwse iconografie van de kruisdraging is het waden van Christus door de 'poel van Cedron' een van de standaard-motieven waarmee Chrıstus' lijdensweg kan worden geëxemplificeerd. ${ }^{23}$ Marrow heeft er op gewezen dat zulke anecdotische motieven een oudtestamentische oorsprong hebben en in het lijdensverhaal werden geïncorporeerd als uitvloeisel van de middeleeuwse methode van allegorische bijbel-exegese. Hij heeft daarbij benadrukt dat een bewust blijk van de inhoudelijke zin van deze 
anecdotiek veelal niet meer uit de voorstelling valt op te maken. Ook in Bruegels schilderij zijn geen tekenen van een besef van dit theologisch-exegetisch gedachtengoed, zelfs geen aanwijzing dat Bruegel hier de 'poel van Cedron' heeft willen uitbeelden. Maar een doorwerking van deze iconografische traditie en vooral van de laatmiddeleeuwse tendens tot verhevigde lijdensschildering die daarin besloten ligt, l1jkt toch onmiskenbaar aanwezig.

Volgens het door Jan van Amstel 'verfijnde' stramien van opposities in de figurale voorstelling van het geschilderde landschap, waarbij de zestiende-eeuwse mens het tegendeel doet van wat men verwacht dat hy zou moeten doen in het licht van de persoon en de boodschap van Chrıstus, valt ook de scène te begrijpen van een groep mannen op de achtergrond, die bij het passeren van de vertegenwoordigers van de rechterlijke macht achter Christus, hun hoofddeksels afnemen (afb 2). Zij kıken nadrukkelık naar deze hoogwaardigheidsbekleders en veraanschouwelıjken zo een varıant op een thema dat ook een belangrijke rol speelt in Van Amstels Intocht: onwaaracht1g eerbetoon Hier gaat het om ongepast eerbetoon, de passanten doen het omgekeerde van wat zlj elgenlyjk zouden moeten doen: Chrístus eer bewijzen in plaats van zijn moordenaars.

Hoe ver moet men nu gaan bij het zien van verbanden tussen afzonderlijke scènes in deze voorstelling? Het is in elk geval zo - dat bewiıst laatstgenoemde scène wel -, dat sommige scènes en motreven niet alleen of niet direkt in relatie tot Christus moeten worden bezien, maar ook of in eerste instantie in relatie tot ándere scènes. Dat geldt bijvoorbeeld voor de twee mannen en een kind op de voorgrond die, achterom kijkend naar de aanhouding van Simon van Cyrene, kersen eten uit een schaal (afb. 2). De verhalende context van z1jn tegenstribbelende vrouw, het feit dat beiden als boeren z11n weergegeven en hun marktwaar - een omgevallen melkkan en een lam waarvan de poten zijn samengebonden (1) - één moment aan hun aandacht ontsnapt, waardoor dieven zich van hun waar kunnen meester maken en zich met balen over de schouder uit de voeten maken, suggereert dat ook de kerseneters van de gelegenhe1d misbru1k hebben gemaakt. Het gedrag van deze personen staat op het eerste gezicht niet in direct kontrast tot Christus, maar aangezien hier, net als in Van Amstels Intocht, van de beschouwer verlangd wordt dat hij een verhalende samenhang uit individuele scènes construeert, is uiteindelıjk de relatie van het ogenschjjnlyjk zo vriendelıjke motief van de kerseneters tot Christus wel aan de orde. Gezien vanuit de aan elkaar verwante thema's die aan de basis blyken te liggen van alle tot nog toe geanalysecrde scènes - 'compassie', 'aandacht', 'bijstand', 'mededogen', 'eerbetoon' en vooral de tegendelen hiervan-, past ook het detail van de kerseneters in deze samenhang.

Maar hoe is het dan gesteld met kleine anecdotes als de jongens, links op de achtergrond, die over modderige waterplassen springen; hoe ver moet de beschouwer deze samenhang uitspinnen? Wordt de beschouwer geacht een uiterlijke overeenkomst te zien met de $\varphi$ versteek door het modderige water van de kar met de moordenaars? (Men lette dan ook op de twee jongens die bij het doorwaden van dit water elkaar op stenen wijzen die de oversteek kunnen vergemakkelıjken.) Moet deze speelse preoccupatie met modder in verband met Christus' lijden worden gezien? Ligt hier een associatief verband tussen 'het liff droog houden', 'liffsbehoud' en Christus' he1lsdaad, zijn offer voor het 'eeuwige-lijfsbehoud' van de mens? Staat aandacht voor zichzelf hier tegenover geven om de ander? Zelfs triviale detals als de ruiter op de achtergrond die over de hals van zijn paard in slaap lijkt te zijn gevallen (afb.4), de man die even terugloopt om zijn afgevallen muts op te rapen en het reeds vermelde detall van de man die zijn kind plaagt door zijn baret buiten zijn bere1k te houden, passen binnen deze samenhang, moeten deze als variaties op het thema 'gebrek aan aandacht' of 'ongepaste aandacht voor trivialiteiten' worden uitgelegd? Lnzovoort. ${ }^{24}$ 
Aan de ene kant moet $\mathrm{tk}$ constateren, dat $\mathrm{k}$ met deze vragen over de rand van het objectief bewısbare ben gegaan Maar tegelıjkertıjd denk $1 \mathrm{k}$ dat het stellen van deze vragen historisch gezien juist en zelfs noodzakelıjk is en tot het oorbare wetenschappelyjke discours behoort De beeldtaal waarvan Bruegel zich in dit schilderiy heeft bediend, lijkt te zijn gericht op het subjectief construeren door de beschouwer - binnen het door de voorstelling aangererkte religieus-morele raam werk - van betekenisvolle verbanden en op het pogen individuele details binnen deze samenhang te zien en te doorzien Het accepteren van de onzekerherd ten aanzien van de vraag of men alle figuren en handelingen wel 'juist' interpreteert, komt dichter bij de bedoelingen van de schilder dan het alleen accepteren van 'zekere', bew1jsbare interpretaties zoals men dat in het wetenschapsbedri|f gewend is te doen Het verplaatsen van de bijbelse gebeurtenissen naar de moderne, zestiende-eeuwse tijd en het doortrekken van de religieuze en morele implicaties daarvan naar de individuele mens, geschiedt reeds in het schilderij. De beschouwer zet slechts deze beweging voort De vraag hoe ver men, of beter, hoe ver 11) als individuele beschouwer daarbij moet gaan, is het eigenlijke onderwerp van dit schilderij Persoonlık denk $1 \mathrm{k}$, dat het antwoord moet zıjn ik kan daarbij niet ver genoeg gaan ${ }^{25}$

\section{NOTEN}

* Graag wil ik mijn dank betuı gen aan Mark Meadow en Ber nard A1kema voor onze ge sprekken, die mıj bij de voor bereidıng van dit artıkel tot hulp zljn geweest

$\mathrm{J}$ Bruyn, Over bet voortleven der middeleewnen, (1naug rede) Am stcrdam 196r, 1dem, 'Het pro bleem van het realisme in de zeventiende eeuwse Hollandse kunst van Hulringa tot heden', in Theoretzsche geschuedents $\mathrm{x} 3$ (1986), 209 218, 1dem, 'Mittel alterliche 'doctrina exemplaris" und Allegorie als Komponente des sog Genrebildes', in Hol landzscbe Genremaleret im 17 Jabr bundert Symposum Berlun 1984 (Jabrbuch Preussuscher Kultur besitz, Sonderband 4), Berlin $1987,33 \quad 59$

$2 J$ Bruyn, 'Toward a Scrupt ural Reading of Seventeenth Century Dutch Landscape Pain ting', in P C Sutton e a, Mas ters of I th Century Dutch Land scape Painting, Amstetdam (R1jksmuseum) Boston (Mu seum of Fine Arts) Philadel phia (Museum of Art) 198788 , $84 \mathrm{ro3}$

3 Verg Bruyns recensie van Pe ter Hecht, De Hollandse Hynschulders Van Gerard Dou tot Adrtaen van der Werff, Amster dam Maarssen/'s Gravenhage 1989, in Ond Holland 105

(I991), $6460,1 \mathrm{~h} \mathrm{~b} 67$
${ }_{4}$ Zie b v H G Fran/, Nreder landssche Landschaftsmaleret $\mathrm{im}$ Leitalter des Manerismus, $2 \mathrm{dln}$, Graz r969, J Muller Hofstede, 'Zur Interpretation von Pieter Bruegels Landschaft Asthet1 scher Landschaftsbegniff und Storsche Weltbetrachtung', in $O G$ von Simson en $H$ Mielke (eds ), Pzeter Bruegel und seme Welt, Berlin I 979, 73 142, en W S Gibson, Mirror of the Earth Ibe World Landscape an Sixteenth Century Flemish Pant ing, Princeton 1989

\section{, C G Stridbeck, Bruegelstudien} Untersucbungen qu den zkonologz schen Problemen bet Pieter Bruegel $d A$ somue dessen Bezuebungen zum nederlandischen Romanusmus, Stockholm 1956 (reprint Soest 1977), 249 252, W S Gibson, Bruegel, London 1977 , I 23, K Demus, in A Balis e a, Flandra lextra muros Vlaamse schilder kunst in bet Kunstbustorisches $M u$ seum te $W$ enen, Antwerpen 1987, $\rightarrow 8$

' R Genalle, 'La Montee au Calvaire de Bruegel l'Ancien', in Jaarboek van bet Konnklyk. Museum voor Schone Kunsten Ant werpen, $1979, \mathrm{I} 43$ I $96,1 \mathrm{~h} \mathrm{~b}$ I $73 \quad$ I 87

7 Demus i 987 (n 5), 80-verg hictonder $n 22$
${ }^{8}$ Ibidem, Genaille 1979 (n 6), 179 Katalog der Gemaldegalerie Flamesche Malerez von Jan van Eyck bus Puter Bruegeld $A$, Wien (Kunsthistorisches $\mathrm{Mu}$ seum) I 98 r, 8 r 84

9 Zie b v E J Sluitter, 'Bele ring en verhulling? Enkele I 7 de eeuwse teksten over de schilderkunst en de iconolog. sche benadering van Noordne derlandse schilderijen ut deze periode', in De Zeventiende Eetu 4 (1988), 328 , de recensie van Chr Brown van Bruyns bidra ge in Sutton 198788 , in Simio lus 18 (1988), 76 8 I

- Strıdbeck 1977 (n 5), 252

Demus 1987 (n 5), 80

2 Wel erken $1 \mathrm{k}$ dat mijn inter pretatie van Bruegels schilderij voortvloett uit cen belangstel ling die $1 \mathrm{k}$ gemeen heb met de beoefenaren van de 'new art history', een belangstelling voor het kijk en interpretatie proces (die gewekt is door de 're ceptic esthetische' analyse methoden welke ontwikkeld $\Delta 1$ in in de literatuurwetenschap (Jauss, Iser) verg mijn attıkel 'De beteken1s van het geschil derde Hollandse landschap van de reventiende eeuw een be schouwing naar aanleiding van enkele recente interpretaties', in Theoretzsche geschiedenzs 16 (1989), 14r e v 
$137 /$ min diss Joachm Patznr bet landschap als beeld van de levens pelgrimage, N1imegen 1985 (Fing ed Joachom Patunr Landscape as an Image of the Palgrimage of I-eff, Amsterdam-Philadel phia I 988 , en mijn bijdrage 'Antithet1cal Iconography in Farly Netherlandish landscape Pannting', in cat tent Bruegel and Netbcrlandish Landscape Panting from the National Callery Prague, Tokyo (The National Museum of Western Art) Kyoto (The National Museum of Modern Art) 1990, 2536

4 Genarlle r979 (n 6)

is Zie F Winkler, 'Die Wiener Kreustragung', in Nederlands Kunsthistorusch Jaarbock o (1958), 83-108 (en afb I-4)

"Het feit dat boeren in de aan dese landschappen in iconogra fisch op/icht geparentecrde marktscenes en keukenstukken van Pieter Aertsen en Joachım Beuckelacr ook cen negatieve excmpel-rol vervullen, beschouw ik als een inhoudelıtke aanw1y $/$ ng tc meer voor een relfde rol in dere landschappen, ric R L Falkenburg, "Iconographical connections betwecn Antwerp landscapes, market scenes and kitchen pieces, i 500 is $80^{\circ}$, in Oud L lolland IO (1988), I14-126 Zie voor de boer als negatief typc in andere, verwante beeldtradities in de resticndc ccuw If J Raupp, Bauernsatoren Entstebung und Lntwacklung des baucrlachen Gonres in der deutschen und neederlandiscben Kunst ca 1470 I570, Niedcraler I 986 Het felt dat het motief van de naar de markt gaande bocten in Bruegels Krusdraging in dere ttadities geworteld is, betekent natuurlijk niet auto matisch dat alle voorstellungen van boeren bi Brucgel een negatieve inhoudelijke lading heb ben cr bestonden ook akonografische traduties met cen posi ticf becld van dc boer, dic Bruegel in anderc werkcn kan hebben angewend $/ 10 \mathrm{R}$ Baldwin, 'Pedsant Imagery and Bruegel's Fall of Icarus', in Konsihustorask I zdskrifl is (1986), roI-is4, en F. M Kava Jer, 'Pieter Brucgel's I all of Icarus and the Noble Pcasant', in Jaarbock wan bet Koninklyk Mu seum voor Scbone Kunsten Antwer pin $1986,83 \quad 9^{8}$
17 Zie voor dese implicaties - de hoolwagen als beeld van aardse preoccupaties en als 'hellewagen' op de na mortis P Van denbrocck, "Nieuw materiaal voor de studse van het Hooswa gen-moticf, in Jaarboek van bet Koninklyk Museum yoor Schone Kunsten Antwerpen 1984, 39-65, $1 \mathrm{~h} \mathrm{~b}$ s s c v, cn 1 dem, "Jheron1 mus Bosch' 'Hoorwagen' enke lc bijkomende gegevens', in Jaarbock wan bet Konmklyk $M_{n}$ scum woor Scbone Kunsien Antwurpen 1987, I07-I 42, 1 h b 107 I I I

${ }^{18}$ De hebrucht van de/e 'bijbelse boeren', dic inherent is in deze traditie, is nog eens onderstreept cn ten opzichte van Aertsens schilder1l aangescherpt doordat nu geen honden maar mensclijke dicven / ich meester maken van hun marktwaar

1) Volgens sommige waarnemers zou Van $A$ mstels Intocht $u$ Jeruqalc $m$ vroeger de sporen van een daternng '( I 5 ) 37 ' hebben ge dragen $71 \mathrm{e} D$ Schubert, Dic Grmalde des Braunschaweger Mono grammiston Lin Bettrag zur Ge scbucble der Nuderlandsscben Male rez der I6 Jabrbunderts, Koln 1970, 198-1 99, $r$ clfs wannecr dit jaartal verkeerd is geleren (en er b v ' 57 ' heeft gestaan), lipkt dit schilderij cerder te $/ 1$ n vervaar digd dan Bruegels Kruidraging

${ }_{20}$ Zie Falkcnburg I985 (n I 3 ), $49 \mathrm{ev}, 73 \mathrm{ev}$, en 1990 (n I 3 ), $32-33$

$=$ Halkenburg $x 990(\mathrm{n} \times 3), 1 \mathrm{~h} \mathrm{~b}$ 32-33 Het handgebaar van de wenende Je/us is uit $/$ onderlitk in de beeldtraditic van de Intocht in Jeruzalem Het enjec voorbeeld uut Brucgels tijd dat Ik naast het schilderij van Van Amstel ken, is een houtgravure van Licven de Witte re I Veldman en $\mathrm{K}$ van Schark, Verbulde boodschap Do Illustra tues van Laeven de Wuttc by 'Dat leven ons Heeren' ( I537), I laar lem-Brussel i 989 , afb i 29 Het nauwkeurig volgen van het b1 belse gegeven - dat ook tot uit drukking komt in de schilde ring van de e, elin ch haar veu ien, en de kleren dic de discipelen op de crelın hebben gelegd (Mattheus 2 I 6 7) - is een goed voorbecld van de 'schriftuurlyke k konografie' die opgeld doet in de restiende ecuw als gevolg van de nieuwe (nict alleen reformatorische) relig1eu/e houding van veel /estiende eeuwers $\angle \mathrm{le} C$, Augustijn,
'Godsdienst in de /esticnde eeuw', in cat tent Ketters on papen onder Fulips II, Utrecht (R1jksmuseum Het Catharıne convent) 1986, 26-40, en R L Falkenburg, 'B1]belse iconografie en spiritualiteit cnkcle be schouwingen over de Neder landse schılderkunst en grafiek van de esticnde eeuw', in I beoreturche geschuedents is (1988), 5 is

${ }^{22}$ Volgens Demus 1987 (n s), 80 , 1s het moticf van de man op de disscl weliswaar 'humoristisch', maar is het 'ontleend aan een ernstig schilderi1 van $C$ Massys' Vermocdelijk bedoelt Demus Massys' Aankomst van Jozef en Marna in Bethlebem (gedat I 543 , Berlajn, Staatliche Museen Preussischer Kultur besit7) - verg B I. Dunbar, "The Landscape Panntungs of Cornelis Massys', in Bulleten der Musces Royaux des Beanx-Arts de Belgrque 23-29 (r 974-8o), afb 3 Ook hicr 71t-op de voorgrond - een boer op de dissel van een paard en wagen, hij wordt vanust dc wagen achter hem om helsd door ecn vrouw (op de achtergrond /1et men de scene van Joref en Maria die tever geefs bij cen boerderij vragen om onderdak voor de nacht) Hier hebben w1 te maken met ecn landschap dat wat de figura le voorstelling betrcft gebaseerd 1s op een in het vroeg-festicndeeeuwse landschap veel vaker voorkomende antuthese tussen b1jbelse protagonisten en boe ren als wereldse en rondige zes t1ende-ceuwse 'antitypen' verg Falkenburg I $99^{\circ}\left(\begin{array}{ll}n & 13\end{array}\right)$ Ilet voorbecld voor Bruegcls schildering van de man op de dissel is dus net waardevri], of 'ernstig', maar brengt op /chclf reeds een negatieve associathe met $71 \mathrm{ch}$ mee

${ }_{23}$ Zic J I 1 Marrow, Passion Iconography in Nortbern Europan Arl of the Lalc Moddle Agcr and Early Renatssance A Shudy of the Iransformation of Sacred Melaphor mino Descriplive Narrative, Korttrlk 1979, I04-109

${ }^{24} \mathrm{Ik}$ meen dat reeds de voor grondscene met de treurende Maria en Johannes de toon ret voor het hele thema complex van aandacht voor en betrokkenherd met Christus Nict al leen gaat het hier om het trad1tionele thema van de compassic, maar ook om ware compassie als ecn innerlipke houding (schouwing, meditatie) versus 
'onecht', uiterlyk misbaat verg Strudbeck 1977 (n 5), 249 252 Het is opvallend dat Johannes en de bijbelse vrouwen, wier betrokkenherd met Christus buiten kuf staat, de rug naar het schouwspel op de achter grond hebben afgewend en in 7ichrelf gekeerd $z 1$ in weergegeven Daar staat tegenover dat verschillende personen naast hen, rechts op de voor grond, wel naar Christus kijken en voor een deel 7 clfs veel uiter lijk misbaar maken In hoevertc deze laatste personen allen als exempla van onwaarachtıge re ligiositeit moeten worden ge zien, ts weer lets wat aan het subjectleve inzicht van de beschouwer van de voorstelling moet worden overgelaten $\Gamma \mathrm{e} 1 \mathrm{t}$ is wel, dat de tegenstelling tus sen hen die Christus sen lijden maat innerlijk onbewogen blijven en hen die innerlyk 'siende' en betrokken $\angle 1 \mid$ n, een thema 15 dat telkens tcrugkeert in de $z$ es tuende eeuwse landschapstrad1 the waarin Brucgels Krmsdraging geworteld is - zie Falkenburg r990 (n 13) Feit 1s ook, dat res tiendc-eeuwse devotie geschrif ten die handelen over het leven en lijden van Christus, urterlyk misbaar afkeuren en innerlijke betrokkenherd propageren - 7le b v Dut es dleven ons lufs bern zhesucristi ( ), Antwerpen (G $\checkmark$ Hombout) I I I2, (KB, Den
Haag 227 A 6), cap CLII

'Nochtans al was haren $[\mathrm{Ma}$ ra's] rouwe soe groot ende onwtsprekelike als si haren he ven eenighen sone dus scandeli ken ter doot sach leyden so en bewees dese salighe moeder nochtan ghcen ontamelic gebaer of onsedelicheit van buten, mer als een eerlijcke statelike vrouwe behieltse desen groten rouwe in hacr besloten seechlic ken sonder eenich musbaer haren lieven kinde met meer ander devote vrouwen als haer susteren ende marta magdalena ende meer andere Meditacie ende aendachticheyt $\mathrm{O}$ devote her ten staet nu inwendeliken op ende haest $u$ met penitencien ende rouwe van binnen ende helpt thesum uwen heere cnde verlosser sijn cruce draghen of ten minsten volcht hem inden wech dyen hi u gheleert ende voren ghetrecken heeft inde draget $u$ liden heymelic met maria die moeder ons heren thesu. so salt verwandelt werden in vroechden "

2s Het thema 'ken u zelf' komt, explicict of impliciet, natuurlyj vaker voor in Bruegels werk, zoals in de prent Elck ( 1 \% 5 ) van Hicronymus Cock naar het ontwerp van Biuegel, lie o a Stridbeck I 977 (n s), passim, verg Baldwin $1986(n \times 6)$ th ben 1 de de bijdrage niet 1 n- gegaan op de religieuse hou ding die aan Bruegels Krasdraging ten grondslag ligt Het religreuze 'ken u zelf' is in de zes t1ende eeuwse Nederlanden geenszins alleen voorbchouden aan de spiritualistische opvat tingen waarmee Bruegels werk herhaaldelijh in verband is ge bracht (b v Stridbeck) de nadruk op de eigen religieuze en morele verantwoordelijkheid die Bruegels kunst zo durdelijk ptopageett, is een algemeen kenmerk van de nueuwe religteuze houding die zich bif velen (katholieken en protestanten) tmantfesteert in de loop van de resticnde ecuw, en vindt ook cen expressie in Bruegels Kruqs draging en de iconografie van de daaraan ten grondslag liggende landschapstraditie (Augustijn 1986, Falkenburg 1988-n 2r) Ik ben dan ook van mening dat Bruegels schilderij en de land schappen van Joachim Patinir, Herrn met de Bles, Cornelis Massys, Jan van Amstel, P1eter Aertsen en Joachim Beuckelaer bedocld zijn om een religreuze houding bij de beschouwer te stimuleren die exact het tegen overgestelde is vath de receptieattutude die Gibson 1989 (n 4), 58-59, voor restiende eeuwse beschouwers van het landschap postuleert - innerlyke afstand ('detachment')

\section{SUMM $\triangle R Y$}

The article is a contribution to the iconology of sixteenth-centuin landscape-panting, and sets out to examine in particular the con nection between the antithethical iconography of the figutal cle ment in landscapes by Joachım Patinir, Herr1 met de Bles and Jan van Amstel, and Pieter Bruegel's C/rist Bearing the Cross in Vien na Also presented and elucidated is the thesis that in this painting Bruegel anticipated with manv cietals the subjective element in the sixteenth century beholder's interpretation, and that this sub jective elcment in the reading of the image was anchored in the 'collective' imagery of early sixteenth-centuiy landscape-pant ing The authot endeavours to demonstrate that the manner of reception prompted by Bruegel's Cbrist Bearng the Cross is compatable with that required of the bcholder of Jan van Am stel's Landscape mith Christ Bearng the Cross in Stuttgart The un rertainty of the bcholder faced with the question of whether a particular subjective interpretation of an individual detal or cettain anecdote is 'correct' should not only be seen as a problem for the twentieth ccntury iconologist but is inherent in the actual panting, and must be judged as a positive element, intended by the painter, in the reception of the image The beholder's pet sonal insight and judgement in issues of good and evil are the true subject of these paintings 